\section{Evaluating Mandarin language students' online experience during Covid-19: A case study from London}

Journal of Education, Innovation and Communication (JEICOM)

56-79

Vol. 2. Issue 2, December 2020 DOI: $10.34097 /$ jeicom-2-Dec2020-4

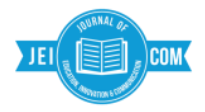

\author{
Li Qing $^{1}$ \\ Dr Fotini Diamantidaki ${ }^{2}$
}

\begin{abstract}
Given the impact of coronavirus, all schools across all sectors public and private, in the United Kingdom closed at the end of March 2020. Closures affected every type of establishment across the UK as well as private language schools. Our case study takes place in London and looks into the student experience in a language Mandarin Chinese school. These language students, as very many across the globe, who attended face-to-face sessions up until that point, have since been studying remotely and joining virtual classrooms via Zoom, one of the multiple video conferencing platforms available. To better evaluate students' online learning experience of remote learning, this study examines the teacherstudent interactions that take place via online means and the students' sense of 'presence' (i.e., cognitive, social, and teaching presence) in order to evaluate the lessons we can learn from the online learning experience, going forward in terms of teaching and learning. This study also presents how meaningful and worthwhile the experience has been and how the sense of 'presence' plays a significant role in the process of online teaching and learning.
\end{abstract}

Keywords: online learning experience, interactions, cognitive presence, social presence, teaching presence

\footnotetext{
${ }^{1} \mathrm{PhD}$ candidate, Institute of Education, University College London, UK. Email: qing.li.17@ucl.ac.uk

${ }^{2}$ Lecturer in Languages Education, UCL centre of Applied Linguistics, UK. Email: f.diamantidaki@ucl.ac.uk
} 
JEICOM, Vol.2, Issue 2, December 2020. Evaluating Mandarin language students' online experience during Covid19: A case study from London. Li Qing \&Dr Fotini Diamantidaki

\section{Introduction}

Given the impact of coronavirus, all schools across all sectors public and private, in the United Kingdom closed at the end of March 2020. Closures affected every type of establishment across the UK as well as private language schools (Scallan et al., 2020; Choi et al., 2020). Our case study takes place in London and looks into the student experience in a language Mandarin Chinese school. These language students, as very many across the globe, who attended face-to-face sessions up until that point, transitioned within a very short amount of time to virtual classes by means of digital resources, in our case Zoom. Although some virtual tools (e.g., Moodle) were previously used for face-to-face lessons, this was the first time that teachers and students transitioned to an entirely online learning set up. To better understand students' online learning experience, especially the impact of nationwide lockdown on L2 Mandarin learning, this study examines teacher-student online interactions and explores students' sense of teaching presence, social presence, and cognitive presence, which contribute to their learning performance and significantly relate to their success and thus further contribute to their feeling of satisfaction (Heckman \& Annabi., 2005; Swan \& Shih, 2005). To investigate the concept of interaction, this study applied the Community of Inquiry model in order to explore the perception of presence in a digital environment and evaluate its significance during the teaching and learning process (Garrison et al., 2000).

\section{Literature Review}

\subsection{Online teaching and learning}

Redmond (2011) suggested four different ways technology in education can be applied according to the parameters of space and time. Firstly, technology is present in the face-to-face mode where teaching and learning are in the same geographical location at the same time. Secondly, when learners and teachers interact in the same space but at a time they choose, such as in asynchronous online discussions. Participants working at the same time but located at different geographical places come next, using different media such as video conferencing. And finally, teachers and learners interact amongst different geographical spaces and also different time zones. Redmond's analysis above allows us to gradually situate learning from face to face to blended to entirely online. Blended learning is therefore defined as "the use of two or more distinct methods of training" (Masie, 2002, p.59) such as face to face and online during one course. Allen and Seaman (2003) continued the debate and defined that a blended course is when "having between $30 \%$ and $80 \%$ of the course content delivered online" and going even further as to identifying an online course mainly "at least $80 \%$ of the course content delivered online" (p.6).

During the last few years, online learning has attracted increasing attention from researchers concerning its advantages and disadvantages for teaching and learning (Teng et al., 2011; Florian \& Zimmerman, 2015). Digital technologies have contributed to improving existing teaching approaches and learning outcomes in a way that it has been embedded into the face-to-face mode and worked in blended and online settings (Hativa \& Goodyear, 2001). However, research also shows that teachers' technology use may be limited due to the lack of technological skills (Burgan 2006, Chen \& Ko, 2010; Chen et al., 2005; Wang \& Chen, 2008). This might lead to an ambiguous assumption of the role that machines play in the classroom environment. Some teachers may consider machines to be a positive 'presence' in the classroom, allowing connectivity and collaboration, whilst some may view it as a 'machine' that causes lack of interaction amongst 
participants: "machines for teaching and learning is a question of presence or absence" (Burgan, 2006, p. 100).

Bain (2004) claimed that teaching should not be limited in any way, whether face-to-face or virtual, pointing out that the main challenge was to make any approach fit the purpose of education and keep learning as effective as possible, in order to engage students on a deeper and more meaningful cognitive level. Marshall (2011) discussed that digital teaching should not compromise "the feeling of community, engagement, focused attention and sense of personal responsibility" as valued by teachers and learners in face-to-face settings (Marshall, 2011, p. 19). Bowen (2012), in defence of online learning, suggested that online resources can be benefiting for educational purposes allowing students and teachers to explore various means of collaboration outside the physical classroom, such as using software systems to improve communication or work together within a digital environment. Florian (2010) suggested that online platforms such as Moodle offer both teachers and learners the opportunity to collaborate beyond the physical realms of the classroom, by sharing resources, giving feedback, having synchronous and asynchronous discussions and so on. Hamad (2017) suggested that Blackboard Collaborate provides real-time annotations and interactive whiteboard for virtual teaching allowing students to download lectures and learning materials at any time and thus caters to their learning style (Hamad, 2017).

From the learners' perspective, studies concluded that the majority enjoyed online learning for its efficiency, flexibility, convenience, and self-pacing opportunities (Wang \& Chen, 2007; Wang et al., 2010; Wuensch et al., 2008). For example, by investigating online learning experiences, Wuensch et al. (2008) deduced that students were satisfied in terms of convenience and self-pacing parameters but were less so with regards to communication with classmates and instructors. Similarly, conducting research in an audio-based learning environment, Park and Bonk (2007) reported that students valued timely feedback from instructors and the dynamic nature of the interaction, but highlighted challenges such as online tool problems and time constraints. Heckman and Annabi (2005) pointed out that the dynamics and mutual interactions during the online learning process contribute to students' learning performance.

\subsection{Presence and the Community of Inquiry Model}

Presence is one's subjective sense of existence during the course of interaction with the social or natural environment, involving the individual's perceptive, cognitive, and affective engagement (Draper et al., 1999). Heeter (1992) proposed that "a sense of presence in a virtual world derives from feeling like you exist within but as a separate entity from a virtual world that also exists" (p.2). This virtual experience may be enhanced if the existence is recognized by other beings in this virtual environment or by the environment itself (Heeter, 1992). He further distinguished subjective experiences from three perspectives: the self, other beings, and the surrounding environment, which corresponded to the three dimensions of presence, respectively: personal presence, social presence, and environmental presence. Personal presence refers to the individual's subjective feeling of being in the virtual world, which varies from person to person. Social presence relates to the individual's feelings towards other beings' existence and the extent of others' reactions to the individual, such as conversations and activities. Environmental presence is concerned with the interaction between the individual and the setting per se, such as to what extent the settings appear to recognize the individual. This further contributes to the individual's sense of being. 
The perception of presence in a digital environment involves the user's feeling of being part of a virtual world and concerns the effectiveness of the digital medium (Ijsselsteijn \& Riva, 2003). Zahorik and Jenison (1998) noted that the degree to which an individual participates being real in a virtual environment is very much determined by the user's own intention and the effective use supported by the digital system in response to the user's action. Daniel (2012) did not regard this sense of being as stable; rather, it is changeable when one moves through the online process over time. Derived from empirical research on students' learning experience in a computer-based environment, Garrison et al. (2000) proposed the Community of Inquiry model (Figure 1) concerning digital education, which is composed of three key elements: cognitive presence, social presence, and teaching presence, with a worthwhile and meaningful educational experience being located within the core.

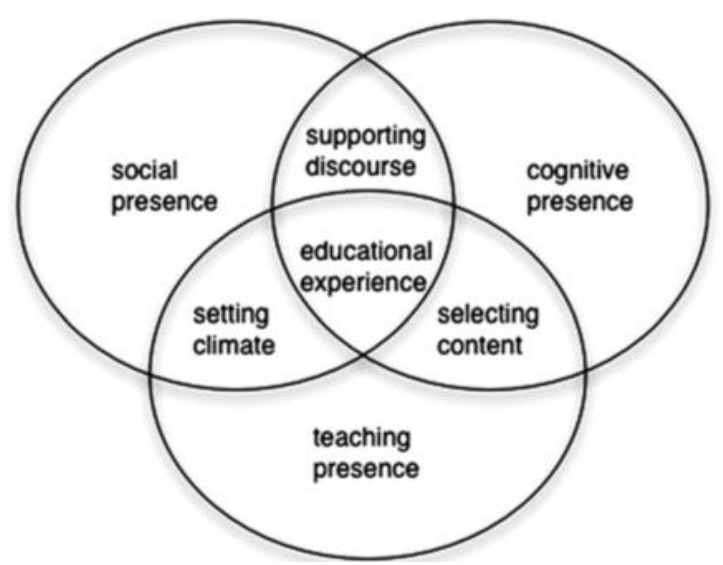

Figure 1. Framework of the Community of Inquiry Model (Garrison et al., 2000)

In this model, cognitive presence refers to the understanding of learning materials, the exploration of the subject, and the resolution concerning the content. This presence involves a reflective and meaning-focused process internal to one's mind, which is essential to learners' worthwhile learning experience to construct their knowledge (Garrison, 2000). Newman et al. (1996 \& 1997) pointed out that online learners may adopt a more serious and worthier style, as a significant difference has been identified between face-to-face and computer-based courses in terms of critical thinking. Specifically, according to their investigation, face-to-face learners received more interaction, whereas computer-based learners generated a higher level of critical thinking. Recent studies have also found that students studying online are involved in higher-level cognitive processes compared with those in physical environments (Hastie et al., 2007; Wang \& Chen, 2007). However, cognitive presence alone is not sufficient enough to develop and sustain higher-order thinking skills in an online educational environment, especially where collaborative work is much needed. What is also important is the extent of the individual's comfort and participation within the virtual community, which implies social presence (Garrison, 2000). 
Social presence refers to how the learners carry themselves, present themselves, project themselves, and interact with others within the online community. The interactions in the community give rise to the individual's sense of being together and the feeling of being connected, as opposed to being isolated (Short et al., 1976; Heeter et al., 2003). In a digital world, communication develops through activities, engagement, management and time spent using the media, all of which help to establish relationships, mutual beliefs and shared knowledge (McInnerney \& Robbert, 2004; Wilhelm et al., 2003). Daniel et al. (2012) postulated that the learners' social presence might be impacted by a sense of belonging to the community, group cohesion, the intensity of members' interactions, etc. It is easier to sustain and enhance cognitive presence in a well-established online community (Garrison, 1997; Gunawardena, 1995).

Teaching presence refers to the learner's perception of the teacher's role as a designer of the course, a guide during learning activities, and an authority in charge of online progress (Hiltz \& Turoff, 2002). The realization of cognitive presence and social presence depends much on the teacher, which is particularly true when it comes to online teaching (Garrison et al, 2000). In fact, the lack of appropriate leadership and direction is a common reason why online teaching or conferences fail (Gunawardena, 1991; Hiltz \& Turoff, 1993). The teacher's behaviour, such as acknowledging student contributions, can affect the efficacy of learning activities to a great extent (Tagg \& Dickenson, 1995). Factors such as course design, facilitation, management, and instruction may also contribute to teaching presence. Generally speaking, learners' social and cognitive presence is very much shaped by teaching presence (Garrison, 2006).

The three types of presence are usually investigated in connection with indicators such as posting and messages. Garrison et al. (2000) categorized these indicators according to these three presences and proposed the coding template shown in Table 1 below: cognitive presence is categorized by triggering event, exploration, integration and resolution. Social presence includes emotional expression, open communication and group cohesion. Teaching presence is composed of course management, building understanding and direct instruction.

To sum up, cognitive presence, social presence, and teaching presence are the main components to understand learners' learning experience in the virtual environment (Garrison, 2006). By applying the Community of Inquiry model, this research examines teacher-student interactions and learners' three dimensions of presence in order to gain insights into learners' experience of online Mandarin learning. Specifically, this research investigates two main questions: 1) What is the nature of the interaction between the teacher and students after the Mandarin course moved online? 2) What are students' three presences like (i.e., cognitive, social and teaching presence) during this online learning experience? 
Table 1. Community of Inquiry Coding Template

\begin{tabular}{|c|c|c|}
\hline Presences & Categories & Indicators / examples \\
\hline \multirow[t]{4}{*}{$\begin{array}{l}\text { Cognitive } \\
\text { Presence }\end{array}$} & Triggering Event & $\begin{array}{l}\text { Recognizing the problems/questions, a sense of } \\
\text { puzzlement }\end{array}$ \\
\hline & Exploration & Information exchange, discussion of ambiguities \\
\hline & Integration & Connecting ideas, combining information \\
\hline & Resolution & $\begin{array}{l}\text { Vicariously applying new ideas, critically assessing } \\
\text { solutions }\end{array}$ \\
\hline \multirow[t]{3}{*}{ Social presence } & $\begin{array}{l}\text { Emotional } \\
\text { expression }\end{array}$ & Emotional interactions, autobiographical narratives \\
\hline & $\begin{array}{l}\text { Open } \\
\text { communication }\end{array}$ & Risk-free expression, acknowledging others \\
\hline & Group cohesion & Encouraging collaboration, helping, and supporting \\
\hline \multirow[t]{3}{*}{$\begin{array}{l}\text { Teaching } \\
\text { presence }\end{array}$} & Course management & $\begin{array}{l}\text { Managing content, setting discussion topics, } \\
\text { establishing discussion groups }\end{array}$ \\
\hline & $\begin{array}{l}\text { Building } \\
\text { understanding }\end{array}$ & $\begin{array}{l}\text { Sharing ideas/thoughts, clarifying confusions, } \\
\text { identifying agreement and disagreement }\end{array}$ \\
\hline & Direct instruction & $\begin{array}{l}\text { Focusing and pacing discussion, providing feedback, } \\
\text { pace of presentation }\end{array}$ \\
\hline
\end{tabular}

Garrison et al., 2000 


\section{Methodology}

\subsection{Mandarin course and participants}

This research investigated classes taught by a Mandarin specialist who was teaching three groups at the preliminary, intermediate and higher level. The students comprised a total of 15 adults (4 females and 11 males). One student went back to her home country, Russia, not long after the school closure but continued to participate in the online Mandarin lessons. Therefore, the course was not affected by transferring to a virtual setting in terms of the number of students. Each group had two Mandarin lessons every week and each lesson lasted two hours. The teacher uploaded teaching materials and set homework on the school's Moodle platform. After the lockdown was announced, Zoom was introduced and functioned as a virtual classroom environment. In addition, groups were set up via Skype by the teacher to facilitate communication outside the class times, for the purposes of answering questions and helping students to complete homework assignments.

\subsection{Data}

Two types of data were collected: text messages between students and the teacher, and questionnaires from students. Digital consent forms and information sheets were sent out and then collected from the students from the start, and the participation was voluntary. Participants were free to withdraw during the research without any consequence and then the data would not be used for this purpose.

\subsubsection{Text messages}

The messages collected in this study were from Skype ${ }^{3}$, where students and the teacher communicated after the lessons over a period of 12 online lessons. For the purposes of this study, the content of messages from the teacher and students were coded into different types, based on the Community of Inquiry model and in reference to other empirical studies (Zhu, 2006; Daniel, 2012). Specifically, the messages between each two lessons were imported into Excel in line with the number of the lessons, and further categorized under the types of messages and the senders (i.e., students and the teacher).

Specifically, there were five types of messages from the teacher in this study:

1. Course facilitation and management.

These were messages concerning the course content or management, for example: "We have finished Chapters 1 and 2; in the next lesson, we will work on Chapter 3"; "Please send your homework to me before the next lesson".

2. Social expression.

This type of expression referred to the teacher's greetings such as "See you all in a minute"; "Hope you all have had a nice day".

\footnotetext{
${ }^{3}$ As Zoom does not receive messages after the lessons and students usually interact with the teacher verbally during the lesson, there were no text messages taken from Zoom.
} 


\section{Responsiveness.}

These were messages in the form of responses to students' questions, comments or enquiries, such as "That's a very positive and genius plan".

4. Technical issues.

Messages of this type referred to the technical use of online media, such as "Please let me know if you cannot access Moodle"; "I think there is a 'record' button when you join Zoom".

5. Other.

These were other kinds of messages that were not relevant to the course per se.

The content of student-sent messages was coded according to four main types:

\section{Cognitive.}

Messages consisted of in-depth inquiries and judgemental/explanatory information. The in-depth inquiries were about the clarification of the course content, such as "I wanted to ask is this cat with rice? I was confused as it says something different in the English translation". Judgmental/explanatory information were concerned with statements made by students with opinions such as "This video is good too but Bai Yu occasionally speaks quickly".

2. Social.

This was composed by a range of responsive messages (e.g., "Enjoy the rest of the day") when students replied to the teacher and the group to show their participation and appreciation, e.g., "That's so exciting".

\section{Technical.}

These messages were concerned with technical issues, e.g., "I'm having some problems with my internet, just trying to get it to work".

4. Other.

These were messages irrelevant to the course, e.g., "My calendar for this month. A positive affirmation calendar".

\subsubsection{Questionnaire}

In order to understand students' subjective sense of social presence, teaching presence, and cognitive presence, a questionnaire (see Appendix) was developed based on the Community of Inquiry model and collected at the end of the 12 lessons. The questionnaire consisted of 30 fivepoint scale questions ${ }^{4}$ and one open question. Specifically, 26 Likert scale questions addressed students' sense of teaching presence, social presence, and cognitive presence. Four questions were about course content and evaluation, effectiveness, speed, and time management. The open question was designed for any additional comments students wished to express. The questionnaire was piloted in advance by two students from a different Mandarin group. The final questionnaire was collected online anonymously. The data were then imported into and analysed by SPSS 26.0. The consistency reliability coefficients of the variables from this questionnaire were above threshold 0.70 (Bernardi, R. A., 1994).

\footnotetext{
${ }^{4}$ The 5 points are: (1) Strongly disagree; (2) Disagree; (3) Neither agree or disagree; (4) Agree; (5) Strongly agree.
} 


\section{Results}

\subsection{Messages}

\subsubsection{Overview}

During the 12 lessons, 685 messages were recorded (Table 2): 376 from students (54.9\%), and 309 from the teacher $(45.1 \%)$. On average, students sent about 31 messages and the teacher sent about 26 messages per lesson. Specifically, this equates to almost 4 messages per student per lesson, a high frequency of the interaction between the teacher and students beyond the lessons, considering the population size and the time frame. Moreover, students' messages outnumbered those sent by the teacher in eight out of the 12 lessons. Interestingly, the largest number of student-sent messages was recorded for Lesson $4(n=44)$, while the lowest was recorded for Lesson $3(n=19)$.

Table 2. Summary of Text Messages (L=Lesson)

\begin{tabular}{|c|c|c|c|c|c|c|c|c|c|c|c|c|c|c|}
\hline $\begin{array}{l}\text { Msg. } \\
\text { Type }\end{array}$ & L1 & L 2 & L3 & L4 & L5 & L6 & L7 & L8 & L9 & L10 & L11 & L12 & Total & $\begin{array}{l}\text { Mean } \\
(\mathrm{SD})\end{array}$ \\
\hline $\begin{array}{l}\text { Student- } \\
\text { sent }\end{array}$ & 34 & 30 & 19 & 44 & 30 & 41 & 42 & 25 & 22 & 32 & 27 & 30 & 376 & $\begin{array}{l}31.33 \\
(7.85)\end{array}$ \\
\hline $\begin{array}{l}\text { Teacher- } \\
\text { sent }\end{array}$ & 21 & 27 & 24 & 25 & 29 & 34 & 28 & 30 & 23 & 17 & 29 & 24 & 309 & $\begin{array}{l}25.91 \\
(4.54)\end{array}$ \\
\hline Total & 55 & 57 & 43 & 69 & 59 & 75 & 68 & 55 & 45 & 49 & 56 & 54 & 685 & $\begin{array}{l}57.08 \\
(9.60)\end{array}$ \\
\hline
\end{tabular}

\subsubsection{Student-sent text messages}

The content of the students' messages was further analysed in order to understand their online participation and engagement on the course (Table 3): 
Table 3. Content Analysis of Student-sent Messages

\begin{tabular}{|c|c|c|c|c|c|c|c|c|c|c|c|c|c|c|c|}
\hline $\begin{array}{l}\text { Main } \\
\text { Type }\end{array}$ & Sub-type & $\begin{array}{l}\mathrm{L} \\
1\end{array}$ & $\begin{array}{l}\mathrm{L} \\
2\end{array}$ & $\begin{array}{l}\mathrm{L} \\
3\end{array}$ & $\begin{array}{l}\mathrm{L} \\
4\end{array}$ & $\begin{array}{l}\mathrm{L} \\
5\end{array}$ & $\begin{array}{l}\mathrm{L} \\
6\end{array}$ & $\begin{array}{l}\mathrm{L} \\
7\end{array}$ & $\begin{array}{l}\mathrm{L} \\
8\end{array}$ & $\begin{array}{l}\mathrm{L} \\
9\end{array}$ & $\begin{array}{l}\mathrm{L} 1 \\
0\end{array}$ & $\begin{array}{l}\mathrm{L} 1 \\
1\end{array}$ & $\begin{array}{l}\mathrm{L} 1 \\
2\end{array}$ & Total & $\begin{array}{l}\text { Mean } \\
\text { (SD) }\end{array}$ \\
\hline \multirow[t]{3}{*}{$\begin{array}{l}\text { Cogniti } \\
\text { ve }\end{array}$} & $\begin{array}{l}\text { In-depth } \\
\text { inquiries }\end{array}$ & 7 & 6 & 4 & 5 & 3 & 8 & 6 & 4 & 6 & 10 & 4 & 9 & $\begin{array}{l}72 \\
(19 \%)\end{array}$ & $6(2.17)$ \\
\hline & $\begin{array}{l}\text { Judgemental/ } \\
\text { explanatory } \\
\text { Information }\end{array}$ & 3 & 2 & 2 & 10 & 4 & 6 & 8 & 5 & 2 & 7 & 6 & 3 & $\begin{array}{l}58 \\
(15 \%)\end{array}$ & $\begin{array}{l}4.83 \\
(2.62)\end{array}$ \\
\hline & (Sub-total) & $\begin{array}{l}1 \\
0\end{array}$ & 8 & 6 & 15 & 7 & 14 & $\begin{array}{l}1 \\
4\end{array}$ & 9 & 8 & 17 & 10 & 12 & $\begin{array}{l}130 \\
(35 \%)\end{array}$ & $\begin{array}{l}10.83 \\
(3.51)\end{array}$ \\
\hline \multirow[t]{3}{*}{ Social } & Affectional & 8 & 1 & 2 & 4 & 2 & 6 & 7 & 3 & 2 & 6 & 3 & 3 & $\begin{array}{l}47 \\
(9 \%)\end{array}$ & $\begin{array}{l}3.91 \\
(2.27)\end{array}$ \\
\hline & Responsive & $\begin{array}{l}1 \\
2\end{array}$ & $\begin{array}{l}2 \\
0\end{array}$ & 11 & 21 & 18 & 19 & $\begin{array}{l}1 \\
3\end{array}$ & 9 & $\begin{array}{l}1 \\
0\end{array}$ & 6 & 11 & 14 & $\begin{array}{l}164 \\
(44 \%)\end{array}$ & $\begin{array}{l}13.67 \\
(4.79)\end{array}$ \\
\hline & (Sub-total) & $\begin{array}{l}2 \\
0\end{array}$ & $\begin{array}{l}2 \\
1\end{array}$ & 13 & 25 & 20 & 25 & $\begin{array}{l}2 \\
0\end{array}$ & $\begin{array}{l}1 \\
2\end{array}$ & $\begin{array}{l}1 \\
2\end{array}$ & 12 & 14 & 17 & $\begin{array}{l}211 \\
(56 \%)\end{array}$ & $\begin{array}{l}17.58 \\
(4.93)\end{array}$ \\
\hline $\begin{array}{l}\text { Technic } \\
\text { al }\end{array}$ & & 1 & 0 & 0 & 0 & 0 & 0 & 2 & 0 & 0 & 0 & 0 & 0 & $\begin{array}{l}3 \\
(0.8 \%)\end{array}$ & $\begin{array}{l}0.25 \\
(0.62)\end{array}$ \\
\hline Others & & 3 & 1 & 0 & 4 & 3 & 2 & 6 & 4 & 2 & 3 & 3 & 1 & $\begin{array}{l}32 \\
(9 \%)\end{array}$ & $\begin{array}{l}2.67 \\
(1.61)\end{array}$ \\
\hline Total & & $\begin{array}{l}3 \\
4\end{array}$ & $\begin{array}{l}3 \\
0\end{array}$ & 19 & 44 & 30 & 41 & $\begin{array}{l}4 \\
2\end{array}$ & $\begin{array}{l}2 \\
5\end{array}$ & $\begin{array}{l}2 \\
2\end{array}$ & 32 & 27 & 30 & 376 & $\begin{array}{l}31.33 \\
(7.85)\end{array}$ \\
\hline
\end{tabular}


1. There were 211 out of 376 messages $(56 \%)$ recorded under the social category, which consisted of the social $(n=47) 9 \%$ and responsive types $(n=164) 44 \%$. It was found that most of the social messages were about greetings and farewells. The majority of the responsive messages were responses to the teacher's requests and other students' posts or discussions. The mean of social messages was around four per lesson, while it was around 14 for responsive ones. In fact, the responsive type exceeded not only the affectional type but also all the other types of messages, which confirmed that interaction between the teacher and the students was the most frequent outside the lessons.

2. It was observed that 130 messages sent by students were cognitive type (35\%). Specifically, there were 72 messages about in-depth inquiries made to clarify aspects of the course content (19\%), representing the second largest number among all the messages. There were 58 messages (15\%) about information posted and shared by students via other online resources (such as YouTube and Twitter), along with expressions of personal judgment or the reasons why they made these recommendations to others. These online resources were relevant to the course but not covered during teaching time.

3. There were only three messages about technical issues during the entirety of the 12 lessons, which suggests that everyone coped well with technology. However, this may have been due to the fact that instructions were sent to them about the use of the technical tools at the beginning, and the IT team from the school was available to help students.

4. There were other messages $(n=32)$ that were recorded but irrelevant to the course, such as discussions about the coronavirus or daily life during the lockdown period. This low figure (9\%) suggests the fact that their communication beyond the lessons on this platform was less about other matters but more about the course.

To summarize, students' messages were more about the responsive interaction (44\%) and in-depth thinking (35\%). Messages about technical $(0.8 \%)$ and other issues $(9 \%)$ were the fewest in number. 


\subsubsection{Teacher-sent text messages}

Table 4: Content Analysis of Teacher-sent Messages

\begin{tabular}{|c|c|c|c|c|c|c|c|c|c|c|c|c|c|c|}
\hline Type & L1 & $\mathrm{L} 2$ & L3 & L4 & L5 & L6 & L7 & L8 & L9 & L10 & L11 & L12 & Total & $\begin{array}{l}\text { Mean } \\
(\mathrm{SD})\end{array}$ \\
\hline $\begin{array}{l}\text { Course } \\
\text { facilitation \& } \\
\text { management }\end{array}$ & 10 & 18 & 12 & 12 & 7 & 9 & 18 & 12 & 17 & 10 & 13 & 14 & $\begin{array}{l}152 \\
(49 \%)\end{array}$ & $\begin{array}{l}12.67 \\
(3.55)\end{array}$ \\
\hline Responsive & 1 & 3 & 12 & 7 & 10 & 14 & 5 & 13 & 4 & 2 & 9 & 3 & $\begin{array}{l}83 \\
(27 \%)\end{array}$ & $\begin{array}{l}6.92 \\
(4.56)\end{array}$ \\
\hline $\begin{array}{l}\text { Social } \\
\text { expression }\end{array}$ & 2 & 1 & 0 & 2 & 2 & 3 & 2 & 2 & 2 & 3 & 3 & 4 & $26(8 \%)$ & $\begin{array}{l}2.17 \\
(1.03)\end{array}$ \\
\hline $\begin{array}{l}\text { Technical } \\
\text { issues }\end{array}$ & 1 & 0 & 0 & 0 & 0 & 0 & 1 & 0 & 0 & 0 & 0 & 0 & $\begin{array}{l}2 \\
(0.7 \%)\end{array}$ & $\begin{array}{l}0.17 \\
(0.39)\end{array}$ \\
\hline Others & 7 & 3 & 0 & 4 & 10 & 8 & 2 & 3 & 0 & 2 & 4 & 3 & $\begin{array}{l}46 \\
(15 \%)\end{array}$ & $\begin{array}{l}3.83 \\
(3.07)\end{array}$ \\
\hline Total & 21 & 27 & 24 & 25 & 29 & 34 & 28 & 30 & 23 & 17 & 29 & 24 & 309 & $\begin{array}{l}25.91 \\
(4.54)\end{array}$ \\
\hline
\end{tabular}

In Table 4, it can be observed that there were 309 messages sent by the teacher, most of which were about course management and facilitation $(n=152) 49 \%$, with an average of 13 messages sent out per lesson. This could suggest that the teacher deployed the text message as the main tool to manage the course beyond the lessons. It was followed by responsive messages $(n=83) 27 \%$, with seven messages per lesson on average. It is interesting to note that this type varied greatly from lesson to lesson, with only one such message collected from Lesson 1 compared with 14 from Lesson 6. It is identified that that only one from Lesson 1 was about the technical issue raised by a student. The total number of social expressions $(8 \%)$ was 26 , while there were only two concerning technical issues $(0.7 \%)$. Other messages $(n=46) 15 \%$ were identified as irrelevant to the course content. To summarize, about half of the messages sent by the teacher were to facilitate or manage the course, with a quarter of the messages being responses to the students.

\subsection{Questionnaire on learning experience}

Table 5 reveals the overall means from the questionnaire, namely between 4.69 and 4.84, with cognitive presence receiving the highest $(\mathrm{M}=4.84)$ and overall evaluation the lowest $(\mathrm{M}=4.69)$. As point 5 in this questionnaire means strongly agree, the high ratings given by the students suggest that they strongly agreed that their online learning was a worthwhile and meaningful experience. 
Table 5. Students' Perception of Presences

\begin{tabular}{|c|c|c|c|}
\hline Presences & Categories & Mean (SD) & Overall mean (SD) \\
\hline \multirow[t]{3}{*}{$\begin{array}{l}\text { Teaching } \\
\text { presence }\end{array}$} & $\begin{array}{l}\text { Instructional } \\
\text { management }\end{array}$ & $4.88(0.35)$ & $4.71(0.20)$ \\
\hline & Building understanding & $4.68(0.18)$ & \\
\hline & Direct instruction & $4.57(0.30)$ & \\
\hline \multirow[t]{3}{*}{ Social presence } & Emotional expression & $4.80(0.31)$ & $4.73(0.53)$ \\
\hline & Open communication & $4.72(0.27)$ & \\
\hline & Group cohesion & $4.69(0.25)$ & \\
\hline \multirow{4}{*}{$\begin{array}{l}\text { Cognitive } \\
\text { presence }\end{array}$} & Triggering event & $4.90(0.20)$ & $4.84(0.60)$ \\
\hline & Exploration & $4.81(0.41)$ & \\
\hline & Integration & $4.89(0.35)$ & \\
\hline & Resolution & $4.77(0.33)$ & \\
\hline \multirow[t]{4}{*}{$\begin{array}{l}\text { Overall } \\
\text { evaluation }\end{array}$} & $\begin{array}{l}\text { Online lessons as a } \\
\text { whole }\end{array}$ & $4.68(0.49)$ & $4.69(0.21)$ \\
\hline & Lesson content & $4.70(0.15)$ & \\
\hline & Effectiveness & $4.85(0.27)$ & \\
\hline & Time management & $4.51(0.76)$ & \\
\hline
\end{tabular}

1. Within the cognitive presence category, triggering events $(M=4.90)$ and integration $(M=4.89)$ were rated the highest among all the variables, which suggests that students strongly concurred that the triggering events posted by the teacher were thought-provoking and they engaged in the course cognitively to a great extent (e.g., connecting ideas and combining information). The score for exploration $(\mathrm{M}=4.81)$ and resolution $(\mathrm{M}=4.77)$ were also high, which means that the course substantially assisted the students to explore information sources and resolve content-related questions.

2. The scores for social presence and teaching presence were similar at 4.73 and 4.71, respectively. In terms of social presence, emotional expression $(\mathrm{M}=4.80)$ indicates that most of the students agreed that the course gave them a sense of belonging for social interaction. Open communication $(\mathrm{M}=4.72)$ could mean that the majority felt comfortable participating in the course discussion and were open to expressing their thoughts. Group cohesion $(M=4.69)$ suggests that this course helped them to develop a sense of collaboration within their groups. Overall, the score for social presence could be interpreted that students had a good sense of belonging and enjoyed the social interaction with other participants. 
3. As to teaching presence, instructional management was rated the highest $(M=4.88)$, followed by building understanding $(\mathrm{M}=4.68)$. This could indicate that the majority of the students were satisfied with the teacher's course management and agreed that the teacher played a positive role in guiding the students' understanding of the course. The relatively low score for direct instruction $(\mathrm{M}=4.57)$ might be explained, to some extent, by the fact that the teacher's instruction, such as her presentation and timely feedback, was not as clear or direct as expected.

4. In terms of an overall evaluation, the online Mandarin lessons were given a value of 4.69 by the students. Specifically, most of the students were pleased with the course as a whole $(M=4.68)$, as well as its content $(M=4.70)$. The course was regarded as effective by the majority $(M=4.85)$. The relatively low time management $(M=4.51)$ may be due to the fact that, during the online lessons, the teacher was unable to adjust the teaching pace as quickly as was the case in the face-to-face classes.

Regarding the open question where comments or feedback were required, most of them were positive $^{5}$ to online learning in terms of its communication and technical usage. Online tools, such as white board, helped them to back up information efficiently.

"I like how we still can communicate like we are in the classroom".

"I can see clearly on my laptop a post to the white board and I can back to all information we are writing in board".

One aspect concerned the feedback given was even better provided online in this study:

"There aren't any problems of taking online courses and even sometimes it's better in some occasions such as receiving more direct detailed feedback".

However, one student raised some issues concerning internet connectivity and Mandarin handwriting in comparison with face-to-face lessons as follows:

"Everything about the course and the online course has been great. The only issues would be that sometimes there are connectivity issues and things can take longer to load as opposed to in a face-to-face course and that it is more difficult sometimes to practice our writing and have this checked or tested by the teacher on the online platform".

This comment suggests that, although there were only three technical issues recorded from the text messages, there would always be a question as to how convenient the technology is for online lessons, as compared with face-to-face lessons, when teachers can give out handouts more easily. This feedback also draws attention to the difficulty of writing practice in online Mandarin learning. In this study, the character writing may be a unique challenge as stroke orders are relatively complicated, especially for students from the background of Latin-based languages. However, this taps into a more generic issue on the specifics of subject pedagogy generated by online teaching.

\footnotetext{
5 the comments reproduced are as written
} 


\section{Discussion and Recommendations}

\subsection{Discussion on messages}

In this study, the number of messages $(\mathrm{N}=685)$ indicates a high frequency of interaction beyond the lesson time. The student-sent messages were more responsive (44\%), which may point to a good sense of community established among the students, as interactions in a community contribute to individual's sense of togetherness (Short et al, 1976; Heeter et al., 2003; McInnerney \& Robbert, 2004; Wilhelm et al., 2003). The cognitive messages (35\%) were recorded as the second highest type sent by student, which indicates that the messaging assisted the students' study beyond the lesson time and facilitated their progress to some extent. This responds positively to Bain (2012)'s call for adopting any approach to assist students' effective learning for the purpose of education. The participants' messages also confirmed that they used digital media mainly for the coursespecific reasons as the other messages (9\%) irrelevant to the course were the fewest in the record. The content of the messages concerning online resources shared with students $(15 \%)$ suggests that the online resources provided a unique opportunity for teaching and learning, as pointed out by Bowen (2012).

Compared with the students, the teacher-sent messages account for $45.1 \%(n=309)$ in comparison with 54.9\% ( $\mathrm{n}=54.9)$, which may negate some doubts on the faculty use of technology (Burgan, 2006; Chen \& Ko, 2010; Chen et al., 2005; Wang \& Chen, 2008). It also shown that the teacher used messages mainly for course facilitation and management (49\%), which may contribute to the course as a whole. Both the teacher and the students experienced only a few technical issues from the messages data. However, these issues may have been resolved by the IT helpdesk set up online by the school. Therefore, further data concerning this issue are suggested to be collected from the IT team and addressed for future research.

\subsection{Discussion on questionnaires}

The data collected from the questionnaires gave a holistic impression of the online lessons, with all scores above 4.50. It indicates that students strongly agreed that they enjoyed the online learning to a great extent. The learners' positive attitude towards online learning is in accordance with other findings (Wang and Chen, 2007; Wang et al., 2010; Wuensch et al., 2008). Specifically, the score for cognitive presence $(\mathrm{M}=4.84)$ was in line with previous findings that online learners are involved in a high level of critical thinking (Newman et al., 1997; Wang \& Chen, 2007). However, in this study, this could also be explained by the fact that all of the students were adults who were capable of grasping information related to their knowledge levels and were more responsible regarding their own study self-discipline. The score for social presence $(\mathrm{M}=4.73)$ could suggest that the students established a close community online, which further helped them to sustain and enhance cognitive presence (Garrison, 1997; Gunawardena, 1995). The teaching presence ( $M=4.71)$ could have contributed to students' cognitive and social presence in this study, as suggested by Garrison (2000, 2006). Moreover, the comments and feedback from the open question confirmed again that most of the students were positive about online teaching, such as its convenience and direct detailed feedback (Wang et al., 2010; Park \& Bonk, 2007; Wang \& Chen, 2007), which is in accordance with the high rating scores from the questionnaire as well as the highly frequent interaction via messaging. 
The downsides of online learning were also brought up in comparison with physical teaching such as the lack of face-to-face supervision. The same issues have been previously addressed by Park and Bonk (2007). The character writing concern raised by the student also increases the attention to the subject-specific difficulties which may occur in online teaching. This character check issue might be particular to Mandarin learning, but it reveals a general concern with inefficient aspects of online education. As Redmond (2011) pointed out, what worked for the face-to-face classroom may be not as effective in the online space to some extent. The challenge is to systematically explore and reinforce the integration of pedagogical practices and technological tools, which will advance digital education in the future (Redmond, 2011; Garrison et al., 2010). In essence, we need to be optimistic as online learning and teaching entails a high level of students' satisfaction and interest (Ali, 2020). The technology has become a potent driving force in transforming the educational landscape across the world especially during these unprecedented circumstances that we all live in (Ali, 2020, 2019).

\subsection{Recommendations}

Given that this was a small-scale research project and messages were only collected from 12 Mandarin lessons, there are more questions concerning online education that need to be explored and answered in the future according to the following parameters: More students could be involved to validate the findings in terms of student numbers and age; More language courses could be investigated and compared to derive a comprehensive picture of online language education; It would be beneficial to compare the difference between online and face-to-face lessons in terms of effectiveness. It would also worth considering individual student's actual environment while attending online lessons, such as the disruption from their background or family interference, as this immediate environment may affect their engagement to some extent; Finally, it would be interesting to determine whether there are any differences when comparing lockdown and normal circumstances, considering that all students and teachers had to migrate to online classes in the lockdown period while the same does not apply for the latter. 


\section{Conclusion}

Conducted during Covid-19, this study provides an insight of online Mandarin teaching and learning that contributes to pedagogical applications for future digital education. By analysing the primary materials (i.e., text messages) and administering questionnaires, this research found that this online Mandarin course was highly valued by students, especially after they had already received face-to-face lessons. The messages data has shown that digital media provided useful platforms for students to communicate and share resources and for the teacher to help them beyond the lessons. These interactions on this digital platform were more for the purpose of learning and less for other irrelevant matters. This further impacted on the students' sense of belonging in a positive way and facilitated the learning progress. The questionnaire data confirmed that the students' sense of cognitive, social and teaching presence was high online, and emphasized that online teaching and learning is valuable. However, we should bear in mind that, students' social presence and the teachers' teaching presence are integrated components contributing to the overall learning experience. Without high-level teaching and social presence, cognitive presence alone may not be valuable enough for a worthwhile and meaningful online education. Therefore, it is recommended to integrate the three presences in teaching to provide learners with a valuable digital education experience. Although there are particular disadvantages, such as the supervision of writing characters for this particular study, the issues concerning online teaching and learning need to be investigated and addressed by researchers and teachers from all teaching fields. In doing so, digital education will bring more benefits within a new and changing education landscape. 


\section{References:}

Ali, W. (2019). The Efficacy of Evolving Technology in Conceptualizing Pedagogy and Practice in Higher Education. Journal of Higher Education Studies, 9(2), 81-95.

Ali, W. (2020). Online and Remote Learning in Higher Education Institutes: A Necessity in light of COVID-19 Pandemic. Higher Education Studies, 10(3), 16.

Allen, I. E., \& Seaman, J. (2003). Sizing the opportunity: The quality and extent of online education in the United States, 2002 and 2003. Retrieved from http://www.sloamc.org/resources/sizing_opportunity.pdf

Bain, K. (2004). What the best college teachers do. Cambridge, MA: Harvard University Press.

Burgan, M. (2006). What ever happened to the faculty? drift and decision in higher education. Baltimore, Md: Johns Hopkins University Press.

Bernardi, R. A. (1994). Validating research when Cronbach's alpha is below 0.70: A methodological procedure. Educational and Psychological Measurement, Vol. 54, 766-775.

Chen, N. S., \& Ko, L. (2010). An online synchronous test for professional interpreters. Educational Technology and Society, 13(2), 153-165.

Chen, N. S., Ko, H. C., Kinshuk, \& Lin, T. (2005). A model for synchronous learning using the Internet. Innovations in Education and Teaching International, 42(2), 181-194.

Chen, N. S., \& Wang, Y. (2008). Testing principles of language learning in a cyber face-to-face environment. Educational Technology and Society, 11(3), 97-113.

Chen, Y. H., Chen, N. S., \& Tsai, C. C. (2009). The use of online synchronous discussion for webbased professional development for teachers. Computers \& Education, 53(4), 1155-1166.

Choi, Byung, Jegatheeswaran, Lavandan, Minocha, Amal, Alhilani, Michel, Nakhoul, Maria, \& Mutengesa, Ernest. (2020). The impact of the COVID-19 pandemic on final year medical students in the United Kingdom: A national survey. BMC Medical Education, 20(1), 1-11.

Draper, J. V., Kaber, D. B., \& Usher, J. M. (1999). Speculations on the value of telepresence. CyberPsychology and Behavior, 2(4), 349-362.

Florian, T. (2010). Confidence-based assessment in Moodle: Insights from teachers, administrators, and programmers. ProQuest Dissertations and Theses.

Gunawardena, C. N. (1995). Social presence theory and implications for interaction and collaborative learning in computer conferences. Paper presentation at The 4th International Conference on Computer Assisted Instruction (Hsinchu, Taiwan).

Gunawardena, C. N. (1991). Collaborative learning and group dynamics in computer-mediated communication networks. In Research monograph of the American center for the study of distance education (Vol. 9, pp. 14 -24). University Park, PA: The Pennsylvania State University.

Garrison, D. R. (1997). Computer conferencing: The post-industrial age of distance education. Open Learning DIP.

Garrison, D. R. (2006). Online collaboration principles. Journal of Asynchronous Learning Networks, 10(1). http://www.sloan-c.org/publications/jaln/v10n1/pdf/

Garrison, D. R., Anderson, T., \& Archer, W. (2000). Critical inquiry in a text-based environment: computer conferencing in higher education. The Internet and Higher Education, 2(2-3), 87105.

Hamad, M. M. (2017). Pros \& Cons of Using Blackboard Collaborate for Blended Learning on Students Learning Outcomes. Higher Education Studies, 7(2), 7. 
Hastie, M., Chen, N. S., \& Kuo, Y.-H. (2007). Instructional design for best practice in the synchronous cyber classroom. Educational Technology and Society, 10(4), 281-294.

Hativa, N., \& Goodyear, P. (2001). Teacher thinking, beliefs and knowledge in higher education. Dordrecht: Kluwer.

Heckman, R., \& Annabi, H. (2005). A content analytic comparison of learning processes in online and face-to-face case study in discussions. Journal of Computer-mediated Communication, 10(2). http://jcmc.indiana.edu/vol10/issue2/heckman.html.

Heeter, C. (1992). Being there: the subjective experience of presence. Presence: Teleoperators and Virtual Environments, 1(2), 262-271.

Heeter, C., Gregg, J., Climo, J., Biocca, F., \& Dekker, D. (2003). Telewindows: case studies in asymmetrical social presence. In G. Riva, \& W. A. IJsselsteijn (Eds.), Being there: concepts, effects and measurement of user presence in synthetic environments (pp. 279-293). Amsterdam, The Netherlands: IOS Press.

Hiltz, S. R., \& Turoff, M. (1993). The network nation: Human communication via computer. Cambridge, MA: MIT Press.

Hiltz, S. R., \& Turoff, M. (2002). What makes learning networks effective? Communications of the $A C M, 45(4), 56-59$.

Ijsselsteijn, W. A., \& Riva, G. (2003). Being there: the experience of presence in mediated environments. In G. Riva, F. Davide, \& W. A. IJsselsteijn (Eds.), Being there: Concepts, effects and measurements of user presence in synthetic environments (pp. 3-16). Amsterdam, The Netherlands: IOS Press.

Leo, T., Manganello, F., Pennacchietti, M., Pistoia, A., Kinshuk, \& Chen, N. S. (2009). Online synchronous instruction: Challenges and solutions. Paper presented at the 9th IEEE International Conference on Advanced Learning Technologies (ICALT 2009), Riga, Latvia.

Masie, E. (2002). Blended learning: The magic is in the mix The ASTD e-learning handbook (pp. 58-63). New York: McGraw-Hill.

Marshall, S. (2001). More face to face, less face to screen. The Chronicle of Higher Education. http://chronicle.com.

McInnerney, J. M., \& Roberts, T. S. (2004). Online learning: social interaction and the creation of a sense of community. Educational Technology \& Society, 7(3), 73-81.

Newman, D. R., Johnson, C., Cochrane, C., \& Webb, B. (1996). An experiment in group learning technology: Evaluating critical thinking in face-to-face and computer-supported seminars. Interpersonal Computing and Technology: An Electronic Journal for the 21st Century, 3(2), 56-72.

Newman, D. R., Webb, B., \& Cochrane, C. (1997). Evaluating the quality of learning in computer supported co- operative learning. Journal of the American Society for Information Science, 2(3), 78-92

Park, Y. J., \& Bonk, C. J. (2007). Synchronous learning experiences: distance and residential learners' perspectives in a blended graduate course. Journal of Interactive Online Learning, 6(3), 245-264.

Redmond, P. (2011). From face-to-face teaching to online teaching: Pedagogical transitions. In G. Williams, P. Statham, N. Brown \& B. Cleland (Eds.), Changing Demands, Changing Directions. Proceedings ascilite Hobart 2011. (pp.1050-1060).

Short, J., Williams, E., \& Christie, B. (1976). The social psychology of telecommunication. London: Wiley. 
Scallan, Samantha, \& Lyon-Maris, Johnny. (2020). The educational impact of COVID-19: Views from UK GP educators and trainees. Education for Primary Care, 1-2.

Swan, K., \& Shih, L. F. (2005). On the nature and development of social presence in online course discussions. Journal of Asynchronous Learning Networks, 9(3), 115-136.

Timothy P Florian, \& Jay P Zimmerman MA. (2015). Understanding by Design, Moodle, and Blended Learning: A Secondary School Case Study. Journal of Online Learning and Teaching, 11(1), 120.

Tagg, A. C., \& Dickenson, J. A. (1995). Tutor messaging and its effectiveness in encouraging student participation on computer conferences. Journal of Distance Education, 3(2), 121-140

Wang, Y., \& Chen, N. S. (2007). Online synchronous language learning: SLMS over the Internet. Innovate: Journal of Online Education, 3(3), 56-78

Wang, Y., Chen, N. S., \& Levy, M. (2010). Teacher training in a synchronous cyber face-to-face classroom: characterizing and supporting the online teachers' learning process. Computer Assisted Language Learning, 23(4), 277-293.

Wilhelm, S., Rodehorst, K., Young, S., Jensen, L., \& Stepans, M. B. (2003). Students' perspective of the effectiveness of an asynchronous online seminar. Journal of Professional Nursing, 19(5), 313-319.

Wuensch, K. L., Aziz, S., Ozan, E., Kishore, M., \& Tabrizi, M. H. N. (2008). Pedagogical characteristics of online and face-to-face classes. International Journal on E-learning, 7(3), 523-532.

Zahorik, P., \& Jenison, R. L. (1998). Presence as being-in-the-world. Presence: Teleoperators, and Virtual Environments, 7(1), 78-89. 


\section{Appendix:}

We would like to invite you to answer the following questions about your experience of online Mandarin learning. This questionnaire is not a test so there are no "right" or "wrong" answers and you do not even have to write your name on it. We are interested in your personal opinion. The results of this survey will be used only for research purposes so please give your answers sincerely, as only this will ensure the success of this survey. If you decide in the end that you would prefer not to participate in this survey, you will be free to opt out without any consequence.

Thank you very much for your help!

\begin{tabular}{|c|c|c|c|c|c|c|c|}
\hline \multirow[t]{3}{*}{ Construct } & \multirow[t]{3}{*}{ Categories } & \multirow[t]{3}{*}{ Items } & \multicolumn{5}{|c|}{ Responses } \\
\hline & & & $\begin{array}{l}\text { Strongly } \\
\text { Disagree }\end{array}$ & $\begin{array}{l}\text { Disagr } \\
\text { ee }\end{array}$ & Neutral & Agree & $\begin{array}{l}\text { Strongly } \\
\text { Agree }\end{array}$ \\
\hline & & & 1 & 2 & 3 & 4 & 5 \\
\hline \multirow[t]{10}{*}{$\begin{array}{l}\text { Teaching } \\
\text { presence }\end{array}$} & $\begin{array}{l}\text { Instructional } \\
\text { Management }\end{array}$ & $\begin{array}{l}\text { 1. The teacher clearly } \\
\text { communicated important } \\
\text { course goals. }\end{array}$ & & & & & \\
\hline & & $\begin{array}{l}\text { 2. The teacher provided } \\
\text { clear instructions on how to } \\
\text { participate in course learning } \\
\text { activities. }\end{array}$ & & & & & \\
\hline & & $\begin{array}{l}\text { 3. The teacher clearly } \\
\text { communicated important } \\
\text { due dates/time frames for } \\
\text { learning activities, e.g., } \\
\text { homework. }\end{array}$ & & & & & \\
\hline & $\begin{array}{l}\text { Building } \\
\text { understanding }\end{array}$ & $\begin{array}{l}\text { 4. The teacher } \\
\text { communicated important } \\
\text { course topics. }\end{array}$ & & & & & \\
\hline & & $\begin{array}{l}\text { 5. The teacher was helpful in } \\
\text { guiding the class towards } \\
\text { understanding the topic in a } \\
\text { way that helped me clarify } \\
\text { my thinking. }\end{array}$ & & & & & \\
\hline & & $\begin{array}{l}\text { 6. The teacher helped to } \\
\text { keep students engaged and } \\
\text { participating in productive } \\
\text { dialogues. }\end{array}$ & & & & & \\
\hline & & $\begin{array}{l}\text { 7. The teacher actions } \\
\text { reinforced the development } \\
\text { of a sense of community } \\
\text { among students. }\end{array}$ & & & & & \\
\hline & $\begin{array}{l}\text { Direct } \\
\text { instruction }\end{array}$ & $\begin{array}{l}\text { 8. I felt comfortable with the } \\
\text { teacher's speaking speed. }\end{array}$ & & & & & \\
\hline & & $\begin{array}{l}\text { 9. The pace of teacher's } \\
\text { presentation was right for } \\
\text { me to understand the key } \\
\text { points of the lesson. }\end{array}$ & & & & & \\
\hline & & $\begin{array}{l}10 . \text { The teacher provided } \\
\text { feedback in a timely fashion. }\end{array}$ & & & & & \\
\hline \multirow[t]{2}{*}{$\begin{array}{l}\text { Social } \\
\text { presence }\end{array}$} & $\begin{array}{l}\text { Emotional } \\
\text { expression }\end{array}$ & $\begin{array}{l}\text { 11. Getting to know other } \\
\text { students gave me a sense of } \\
\text { belonging in the course. }\end{array}$ & & & & & \\
\hline & & $\begin{array}{l}\text { 12. I was able to form } \\
\text { distinct impressions of some } \\
\text { students. }\end{array}$ & & & & & \\
\hline
\end{tabular}




\begin{tabular}{|c|c|c|c|c|c|c|c|}
\hline & & $\begin{array}{l}\text { 13. Online Classroom } \\
\text { provided adequate tools for } \\
\text { social interaction. }\end{array}$ & & & & & \\
\hline & $\begin{array}{l}\text { Open } \\
\text { communication }\end{array}$ & $\begin{array}{l}\text { 14. I felt comfortable } \\
\text { conversing through the tools } \\
\text { provided by online teaching } \\
\text { and learning. }\end{array}$ & & & & & \\
\hline & & $\begin{array}{l}\text { 15. I felt comfortable } \\
\text { interacting with other } \\
\text { students online. }\end{array}$ & & & & & \\
\hline & Group cohesion & $\begin{array}{l}\text { 16. I felt comfortable } \\
\text { disagreeing with other } \\
\text { students while still } \\
\text { maintaining a sense of trust. }\end{array}$ & & & & & \\
\hline & & $\begin{array}{l}\text { 17. I felt that my point of } \\
\text { view was acknowledged by } \\
\text { other students. }\end{array}$ & & & & & \\
\hline & & $\begin{array}{l}\text { 18. Online discussions with } \\
\text { other students help me to } \\
\text { develop a sense of } \\
\text { collaboration. }\end{array}$ & & & & & \\
\hline \multirow[t]{8}{*}{$\begin{array}{l}\text { Cognitive } \\
\text { presence }\end{array}$} & Triggering event & $\begin{array}{l}\text { 19. Problems/Questions } \\
\text { raised by other students } \\
\text { increased my interest in } \\
\text { course issues. }\end{array}$ & & & & & \\
\hline & & $\begin{array}{l}\text { 20. I felt motivated to } \\
\text { explore content-related } \\
\text { questions. }\end{array}$ & & & & & \\
\hline & Exploration & $\begin{array}{l}\text { 21. I utilized a variety of } \\
\text { information sources to } \\
\text { explore problems/questions } \\
\text { raised in this course. }\end{array}$ & & & & & \\
\hline & & $\begin{array}{l}\text { 22. Brainstorming and } \\
\text { finding relevant information } \\
\text { helped me resolve content- } \\
\text { related questions. }\end{array}$ & & & & & \\
\hline & & $\begin{array}{l}\text { 23. Online discussions were } \\
\text { valuable in helping me } \\
\text { appreciate different } \\
\text { perspectives. }\end{array}$ & & & & & \\
\hline & Integration & $\begin{array}{l}\text { 24. I was able to combine } \\
\text { information learned from } \\
\text { different resources to answer } \\
\text { questions raised in course } \\
\text { activities. }\end{array}$ & & & & & \\
\hline & & $\begin{array}{l}\text { 25. I was able to reflect on } \\
\text { course content and } \\
\text { discussions to understand } \\
\text { fundamental concepts in this } \\
\text { class. }\end{array}$ & & & & & \\
\hline & Resolution & $\begin{array}{l}\text { 26. I can describe ways to } \\
\text { apply the knowledge created } \\
\text { in this course in some e- } \\
\text { learning practices or other } \\
\text { non-class related activities. }\end{array}$ & & & & & \\
\hline \multirow{4}{*}{$\begin{array}{l} \\
\text { Overall } \\
\text { impression }\end{array}$} & & & $\begin{array}{l}\text { Very } \\
\text { Poor }\end{array}$ & Poor & Neutral & Good & $\begin{array}{l}\text { Very } \\
\text { Good }\end{array}$ \\
\hline & & & 1 & 2 & 3 & 4 & 5 \\
\hline & & $\begin{array}{l}\text { 27. This online course as a } \\
\text { whole was }\end{array}$ & & & & & \\
\hline & & 28. The course content was & & & & & \\
\hline
\end{tabular}




\begin{tabular}{|l|l|l|l|l|l|l|}
\hline & $\begin{array}{l}\text { 29. The effectiveness of this } \\
\text { online course format was }\end{array}$ & & & & & \\
\hline & $\begin{array}{l}\text { 30. The distribution of time } \\
\text { among presentation, Q \& A, } \\
\text { and time to lighten the } \\
\text { cognitive load (using music, } \\
\text { video) was }\end{array}$ & & & & & \\
\hline
\end{tabular}

Is there anything else you would like to say about your online Mandarin learning?

By submitting this questionnaire, I agree that my answers, which I have given voluntarily, can be used anonymously for research purposes.

Thank you again for your cooperation! 
This journal provides immediate open access to its content on the principle that making research freely available to the public supports a greater global exchange of knowledge. You can Share - Copy and redistribute the material in any medium or format for any purpose, even commercially, under the terms of the Creative Commons Attribution License (CC BY). The use, distribution or reproduction is permitted, provided the original author(s) and the copyright owner(s) are credited and that the original publication in this journal is cited, in accordance with accepted academic practice. No use, distribution or reproduction is permitted which does not comply with these terms. Copyright for this article: (C) 2020 Li Qing and Fotini Diamantidaki. 